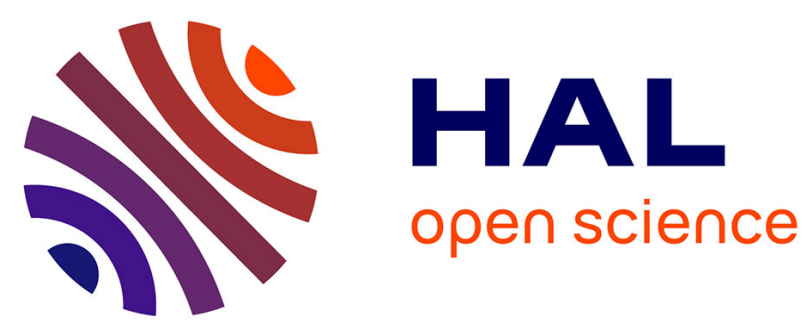

\title{
Light:dark (12:12 h) quantification of carbohydrate fluxes in Crocosphaera watsonii
}

Anthony Dron, Sophie Rabouille, P. Claquin, Patrick Chang, Virginie Raimbault, Amélie Talec, A. Sciandra

\section{- To cite this version:}

Anthony Dron, Sophie Rabouille, P. Claquin, Patrick Chang, Virginie Raimbault, et al.. Light:dark $(12: 12 \mathrm{~h})$ quantification of carbohydrate fluxes in Crocosphaera watsonii . Aquatic Microbial Ecology, 2012, 68 (1), pp.43-55. 10.3354/ame01600 . hal-02433678

\section{HAL Id: hal-02433678 \\ https://hal.science/hal-02433678}

Submitted on 25 Nov 2020

HAL is a multi-disciplinary open access archive for the deposit and dissemination of scientific research documents, whether they are published or not. The documents may come from teaching and research institutions in France or abroad, or from public or private research centers.
L'archive ouverte pluridisciplinaire HAL, est destinée au dépôt et à la diffusion de documents scientifiques de niveau recherche, publiés ou non, émanant des établissements d'enseignement et de recherche français ou étrangers, des laboratoires publics ou privés. 


\title{
Light:dark (12:12 h) quantification of carbohydrate fluxes in Crocosphaera watsonii
}

\author{
Anthony Dron ${ }^{1,2}$, Sophie Rabouille ${ }^{1,2, *}$, Pascal Claquin ${ }^{4,5}$, Patrick Chang ${ }^{1,3}$, \\ Virginie Raimbault ${ }^{4,5}$, Amélie Talec ${ }^{1,2}$, Antoine Sciandra ${ }^{1,2}$ \\ ${ }^{1}$ UPMC Univ Paris 06, UMR 7093, LOV, Observatoire océanologique, 06234, Villefranche-sur-mer, France \\ ${ }^{2}$ CNRS, UMR 7093, LOV, Observatoire océanologique, 06234, Villefranche-sur-mer, France \\ ${ }^{3}$ CNRS, UMR 7009, Biologie du développement, 06230, Villefranche-sur-mer, France \\ ${ }^{4}$ Université Caen Basse-Normandie, FRE BIOMEA, 14032 Caen, France \\ ${ }^{5}$ CNRS INEE, FRE BIOMEA, 14032 Caen, France
}

\begin{abstract}
Light:dark (12:12 h) quantification of cellular carbohydrate fluxes was conducted with the unicellular, $\mathrm{N}_{2}$-fixing cyanobacterium Crocosphaera watsonii WH8501 grown in continuous cultures under conditions of diazotrophy. As commonly observed in photoautotrophs, C. watsonii accumulates photosynthetic products as carbohydrates, which thereafter serve as an internal energy reserve for energy-demanding processes. Our goal was to further discriminate between cellular pools with different sizes to observe their respective dynamics. Total cellular carbohydrate as well as the cellular carbohydrate pools showed a diel cycle of accumulation and decrease. Total cellular carbohydrate contents represented 45 and $32 \%$ of the cellular carbon content at the end of the light and dark period, respectively. The observed decrease in cellular carbohydrate was not only due to carbohydrate catabolism but also to their release in the environment as extracellular polymeric substances (EPS), including soluble EPS and transparent exopolymeric particles (TEP). The occurrence of such excretion during the exponential growth of $C$. watsonii appears as part of the metabolic regulations that participate in maintaining a daily carbon:nitrogen balanced growth. About $10 \%$ of the total carbon cell content is excreted daily as soluble EPS. TEP, which are formed from dissolved precursors (including some soluble EPS) released by C. watsonii, increased during the dark period, when they represented up to $3.6 \%$ of total carbon cell content. Such recurrent release of carbohydrate by populations of $C$. watsonii is expected to stimulate the microbial loop in warm, oligotrophic oceans.
\end{abstract}

KEY WORDS: Carbon - Extracellular polymeric substances $\cdot$ EPS $\cdot$ Transparent exopolymeric particles $\cdot$ TEP $\cdot$ Diazotroph $\cdot \mathrm{UCYN} \cdot$ Continuous culture $\cdot$ Excretion

\section{INTRODUCTION}

In aquatic environments, carbohydrates are a major component of dissolved organic carbon (Kepkay 2000, Hertkorn et al. 2006) and are mainly found as extracellular polymeric substances (EPS). Owing to their sticky nature, these polymeric carbohydraterich molecules (Kepkay 2000) participate in the aggregation and sedimentation dynamics of marine particles (Engel 2000) and can trigger or enhance exportation of organic matter into the deep ocean (Thornton 2002). Thus, EPS play a significant role in the biogeochemical cycle of elements as well as in food web structure (Passow 2002). EPS show various forms that can be free or strongly attached to cells (Passow 2002). Most EPS are found in the free fraction, constituted by (1) low and high molecular weight soluble EPS (LMW soluble EPS and HMW 
soluble EPS, respectively) (Underwood et al. 1995, 2004, Klein et al. 2011) and (2) a particulate fraction (Thornton 2002) called transparent exopolymeric particles (TEP) (Alldredge et al. 1993). EPS are excreted by numerous phytoplanktonic organisms and bacteria (Myklestad 1995). Such excretion has largely been documented in eukaryotic microalgae (Passow 2002, Claquin et al. 2008), where it can vary from a few percent to $70 \%$ of the photosynthetic carbon uptake, depending on species and growth conditions (Claquin et al. 2008).

Recently, EPS excretion has also been observed in $\mathrm{N}_{2}$-fixing (diazotrophic) organisms such as Crocosphaera watsonii (Webb et al. 2009, Sohm et al. 2011), a unicellular, $\mathrm{N}_{2}$-fixing cyanobacterium (UCYN) classified within group B (UCYN-B) (Zehr et al. 2001). Because they contribute significantly to the provision of new nitrogen into tropical and subtropical areas, UCYN are depicted as keystone taxa in the carbon and nitrogen cycles (Zehr et al. 2007). It is suspected that UCYN are important drivers of nitrogen availability in oligotrophic areas of the world ocean, and new features have been pointed out in their physiologies that could further affect the biogeochemistry of their environment. Among these features is carbon excretion, which has been visually observed in several strains of $C$. watsonii (Webb et al. 2009): batch cultures of the class of large cells (WH0006 and WH0004 strains) appeared to consistently produce 'extracellular material' that increased the medium viscosity, while smaller cells (including the WH8501 strain) did not; this material was identified as EPS of polysaccharide nature. However, small cells $(\sim 3 \mu \mathrm{m}$ diameter) growing in batch cultures seem to constitutively excrete as well (Sohm et al. 2011). All cells produced this material during the exponential growth phase and under both non-diazotrophy and diazotrophy conditions. In addition, Biegala \& Raimbault (2008) reported that C. watsonii-like cells, observed in a coral lagoon in the southwest Pacific Ocean, were found in a matrix and therefore suggested that this organism produced extracellular carbohydrate in situ. Hence, the question arises as to what growth conditions trigger this process as well as to what amount of organic carbon is released by natural populations of nitrogen fixers in the oligotrophic gyres. Such estimation on a global scale first requires more data on the potential growth of diazotrophs and precise quantification of the carbon release that is concomitant to their growth.

The cellular carbohydrate content should fluctuate because it constitutes an internal storage of energy for the organism, used via catabolism (Gallon et al.
1988, Colón-López et al. 1997). In the UCYN-C Cyanothece sp., for instance, intracellular carbohydrate storage alternatively rises during photosynthesis and falls during $\mathrm{N}_{2}$ fixation during $12 \mathrm{~h}$ light and $12 \mathrm{~h}$ dark periods, respectively (Schneegurt et al. 1994). Dron et al. (2012) monitored the daily fluctuations of the carbon and nitrogen cell quotas in Crocosphaera watsonii WH8501 under conditions of diazotrophy and showed an accentuated decrease of the former during nitrogen fixation. The quantification of these light:dark cellular carbon content fluctuations revealed an imbalance with nitrogen incorporation into the biomass while the daily average carbon: nitrogen ratio was conserved, suggesting that cells excreted carbon, probably as carbohydrate (Dron et al. 2012).

The main purpose of the present study was to dispel the current uncertainty on the significance of EPS production in Crocosphaera watsonii. We performed close monitoring of C. watsonii WH8501 ( 3 $\mu \mathrm{m}$ cell diameter) grown in duplicate continuous cultures maintained under a $12 \mathrm{~h}$ light:12 h dark cycle and conditions of diazotrophy. The carbohydrate mass budget was quantified, with further discrimination among different cellular and extracellular pools, to assess whether the excretion process is important in regard to the environment and to understand when C. watsonii releases carbon.

\section{MATERIALS AND METHODS}

\section{Experimental set-up}

The dataset presented herein originates from an experimental set-up described by Dron et al. (2012). We describe the methods used to quantify all carbohydrate pools, which are the data specific to the present manuscript. Results of high frequency measurements of cell abundance, cell volume, cellular carbon content and cellular nitrogen content, used here to normalize carbohydrate results, were discussed by Dron et al. (2012).

This experiment was run in continuous cultures that are best suited both to maintain cultures in the exponential growth phase and to monitor them over long periods of time (Bernard et al. 1996). The culture medium was renewed at a fixed rate (the dilution rate), and the culture reached an equilibrium state in which the culture kept growing exponentially at a growth rate that equaled the dilution rate; culture properties (such as biomass concentration, growth rate, etc.) then show constant, daily average 
values (see Bernard et al. 1996 and Sciandra \& Ramani 1994 for a detailed description of continuous cultures and their mathematical description). In the cultures of the present study, light was the limiting factor, while all nutrients were provided abundantly and following the proportion proposed for planktonic diazotrophs (Chen et al. 1996). The experimental set-up used in the present study was identical to that presented by Dron et al. (2012) and is therefore only briefly described here. Monocultures of Crocosphaera watsonii strain WH8501, isolated in the mid-1980s in the western tropical South Atlantic Ocean (Waterbury \& Rippka 1989), were grown in automated culture devices that allowed close, high frequency monitoring of several parameters (Malara \& Sciandra 1991, Bernard et al. 1996). The photobioreactor system consisted of 2 replicate, doublewalled vessels (C1 and $\mathrm{C} 2$ ) containing isolated growth medium volumes of 5 l. Milli-Q water circulated from a water bath into the double wall provided a constant, optimal growth temperature of $27^{\circ} \mathrm{C}$ (Webb et al. 2009). Light was provided with 2 sets of 10 fluorescent tubes (OSRAM, DULUX ${ }^{\circledR} \mathrm{L}$, 2G11, 55W/12-950, LUMILUX DE LUXE, daylight), positioned on 2 opposite sides of the vessels. Irradiance followed a sinusoidal, $12 \mathrm{~h}$ light:12 $\mathrm{h}$ dark cycle with a maximum value of $130 \mu$ mol quanta $\mathrm{m}^{-2} \mathrm{~s}^{-1}$ in the middle of the light period. According to the 'Hawaii Ocean Time-series - Data Organization and Graphical System' (http://hahana.soest. hawaii.edu/hot/hot-dogs/interface.html), this light intensity corresponds to the value measured at $60 \mathrm{~m}$ depth at Stn ALOHA. Irradiance was continuously recorded by immersing the spherical collector of a quantum scalar irradiance meter (Biospherical Instruments QSL-2100) into the cultures. Magnetic stirrers were used to homogenize the cultures. Bubbling was provided with air previously filtered through activated charcoal and a Whatman filter $(0.2 \mu \mathrm{m})$. Cultures were grown in a modified YBCII culture medium (Chen et al. 1996), prepared from aged, Mediterranean Sea surface water (initial salinity 38.00, collected at the permanent 'Point B' station $\left[43^{\circ} 41^{\prime} 10^{\prime \prime} \mathrm{N}\right.$ and $\left.\left.7^{\circ} 19^{\prime} 00^{\prime \prime} \mathrm{E}\right]\right)$. Collected seawater was first filtered through $1 \mu \mathrm{m}$ Whatman filters and stored in the dark at $20^{\circ} \mathrm{C}$ for $1 \mathrm{mo}$. Before use, the seawater was filtered through $0.1 \mu \mathrm{m}$ Whatman filters, then diluted with Milli-Q water up to a final salinity of 35.00 and lastly autoclaved at $121^{\circ} \mathrm{C}$ for $20 \mathrm{~min}$. After cooling and sterile addition of macro- and micronutrients, the medium was transferred to the photobioreactors through a $0.22 \mu \mathrm{m}$ sterile filter. Tubing for culture medium supply and culture removal was connected to the same peristaltic pump to ensure a constant culture volume. The dilution rate was $0.2 \mathrm{~d}^{-1}$. Axeny is not possible in such continuous cultures, but the level of bacterial contamination, which remained low, was carefully checked by flow cytometry (DNA, SybrGreen stained). Bacterial cells found in the cultures had an average volume of $0.07 \mathrm{~m}^{3}$, while the average value for a $C$. watsonii cell was $14.3 \mu^{3}$ (Dron et al. 2012). Using the conversion factor between bacterial biovolume and carbon or nitrogen content of bacteria from the BATS site (Gundersen et al. 2002), the total carbon and nitrogen associated with C. watsonii represented $99.6 \%$ of both total particulate carbon and nitrogen in the cultures.

Cultures were grown for at least 15 generations under the described conditions before sampling began. High frequency measurements were conducted on $\mathrm{C} 1$ and $\mathrm{C} 2$ at steady state for 4 consecutive days (Days 1 to 4), during which all parameters listed below were measured in triplicate. The $24 \mathrm{~h}$ day was subdivided by the letters L or D (for light and dark periods, respectively) followed by integers, e.g. D1 refers to the first hour of the dark period and so forth.

\section{Cell abundance and particulate organic carbon}

Cell abundance and average cell volume were measured every hour using a Coulter Counter (Beckman, Multisizer 3). Cell size is presented as equivalent spherical diameter. The total particulate organic carbon in the cultures was determined daily at L12 and D12. Samples of $5.8 \mathrm{ml}$ were filtered onto precombusted $\left(6 \mathrm{~h}\right.$ at $\left.450^{\circ} \mathrm{C}\right)$ glass fiber carbon filters (Whatman) and dried at $60^{\circ} \mathrm{C}$ before analysis with a CHN analyzer (Perkin Elmer, 2400-II). Carbon cell contents were estimated using the cell abundance measured at the time of sampling.

\section{Transmission electron microscopy}

Samples for transmission electron microscopy observations were taken at L6 during Day 1 and Day 4. A sample $(1 \mathrm{ml})$ of culture was centrifuged at $13200 \mathrm{rpm}(16100 \times$ g, Eppendorf, 5415D) for $1 \mathrm{~min}$ at $20^{\circ} \mathrm{C}$. The supernatant was removed, and the pellet was immediately fixed (Crowther \& Whittaker 1986, Meedel et al. 2007) by a 30 min incubation at $20^{\circ} \mathrm{C}$ in $0.2 \mathrm{M} \mathrm{Na}$-cacodylate $\mathrm{pH} 7.2$ containing $2.5 \%$ glutaraldehyde and $0.34 \mathrm{M} \mathrm{NaCl}$. After rinsing once 
in the aforementioned buffer without fixative, cells were post-fixed on ice for $30 \mathrm{~min}$ in $1 \% \mathrm{OsO}_{4}, 1.5 \%$ potassium ferrocyanide, $2.5 \%$ bicarbonate buffer, $\mathrm{pH} 7.2$, and $0.34 \mathrm{M} \mathrm{NaCl}$. Cells were stained en bloc overnight at $4^{\circ} \mathrm{C}$ in $2 \%$ uranyl acetate on a rotary shaker. After dehydration in an ethanol series of 50, $60,70,80,90,95 \%$ and $4 \times 100 \%$ for $10 \mathrm{~min}$ each step, cells were embedded in a 1:1 mixture of LR White (Agar Scientific):ethanol for $30 \mathrm{~min}$ followed by $100 \%$ LR White overnight at $4{ }^{\circ} \mathrm{C}$ on a rotary shaker. The next day, samples were embedded in gelatin capsules, and polymerization followed at $4{ }^{\circ} \mathrm{C}$ with UV light. Ultra-microtome silver sections were post-stained with uranyl acetate and lead citrate and observed with a Hitachi H-600 electron microscope at an accelerating voltage of 75 or $100 \mathrm{kV}$. Images obtained from the transmission electron microscopy were digitally scanned.

\section{Total cellular carbohydrate, cellular carbohydrate pools and soluble EPS}

Quantitative analysis of total cellular carbohydrate and cellular carbohydrate pools were performed in 3 replicates of $5.8 \mathrm{ml}$ of culture taken every $4 \mathrm{~h}$. Total carbohydrates were experimentally quantified on different sets of triplicate samples. Samples were filtered through $1 \mu \mathrm{m}$ polycarbonate filters, which retained Crocosphaera watsonii cells, and filters were stored at $-80^{\circ} \mathrm{C}$ until further analysis (Fig. 1).

For determination of total cellular carbohydrate, the Crocosphaera watsonii cells which were retained onto the filter were first resuspended in $1 \mathrm{ml}$ of Milli$\mathrm{Q}$ water. Then, $1 \mathrm{ml}$ of $5 \%$ phenol and $5 \mathrm{ml}$ of sulfuric acid were added to the sample and vortexed to extract all carbohydrates, i.e. simple sugars, oligosaccharides, polysaccharides and their derivatives

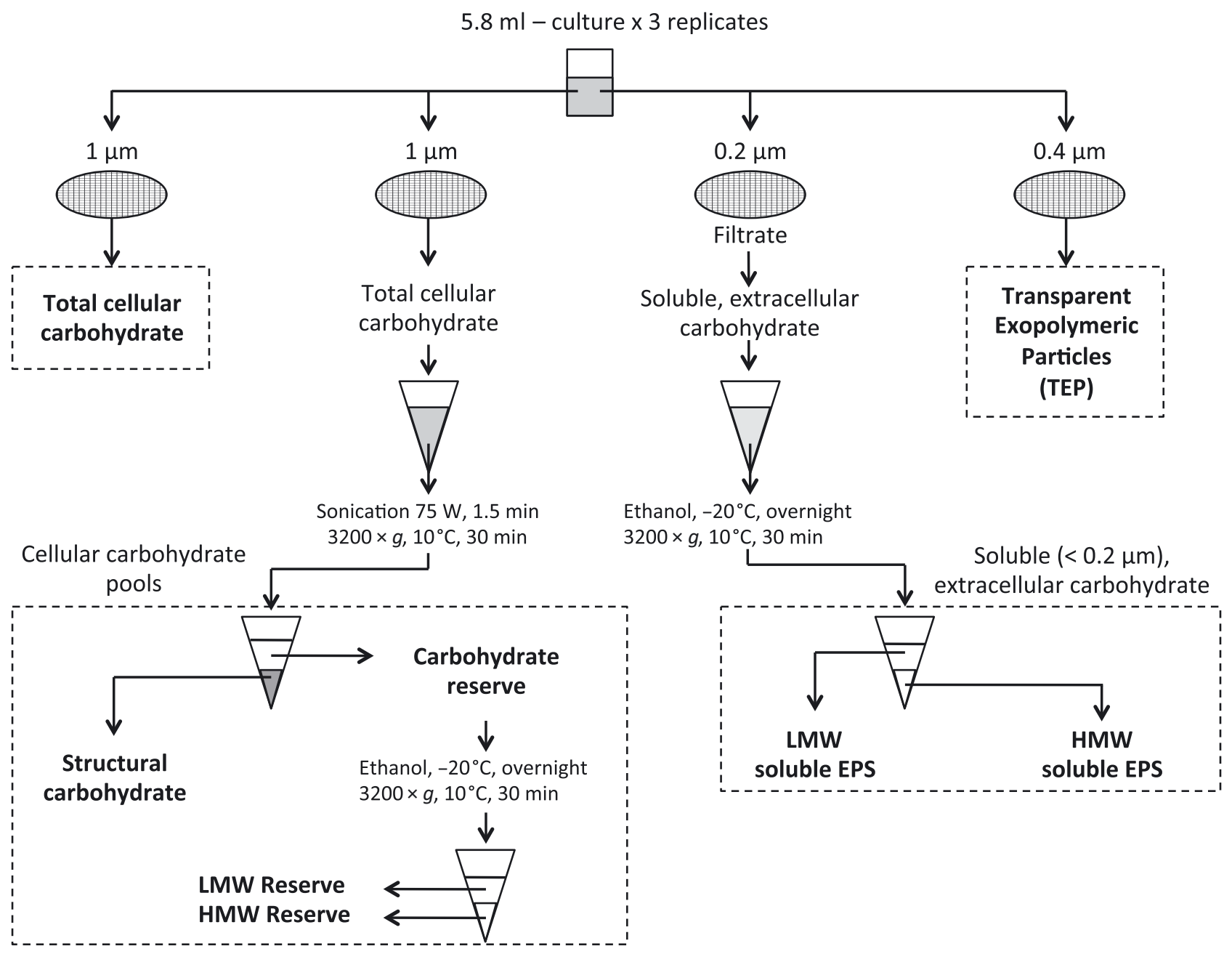

Fig. 1. Extraction procedure of both intracellular and extracellular carbohydrate pools. LMW: low molecular weight, HMW: high molecular weight, EPS: extracellular polymeric substances 
(Dubois et al. 1956). After 30 min extraction at $20^{\circ} \mathrm{C}$, total cellular carbohydrate levels were measured by colorimetry with glucose as standard (linear regression, $r^{2}=0.99$ ) (Dubois et al. 1956), which provides estimates of carbohydrate contents expressed as a mass of equivalent glucose per sample.

Samples for determination of cellular carbohydrate pools were first resuspended in $3 \mathrm{ml}$ of Milli-Q water, and cell lysis was obtained by sonication $(1.5 \mathrm{~min}$ at $75 \mathrm{~W})$ before centrifugation $(3200 \times g$, at $20^{\circ} \mathrm{C}$ for $30 \mathrm{~min}$ ). Two cellular carbohydrate pools were thereby identified through differential centrifugation. To the best of our knowledge, such fractionation has not been reported in the literature; we hypothesized that the smaller fraction was representative of reserve molecules, while the larger pool included structural material. The supernatant containing carbohydrate reserve was then separated from the pellet containing structural carbohydrate (Fig. 1). Similar to the methodology proposed by Underwood et al. (1995) for the fractionation of reserve EPS, further separation of carbohydrate reserve samples into 2 distinct pools of LMW $(<100 \mathrm{kDa})$ and HMW (>100 kDa) (de Brouwer \& Stal 2001) was performed according to their solubility or precipitation in ethanol. The reserve carbohydrate solutions were thus transferred to centrifugation tubes containing cold ethanol $(75 \%, v / v)$, and the polymeric material was precipitated at $-20^{\circ} \mathrm{C}$ overnight (Fig. 1) (Underwood et al. 2004). After centrifugation at $3200 \times \mathrm{g}$, at $10^{\circ} \mathrm{C}$ for $30 \mathrm{~min}$, pellets containing the HMW fraction of carbohydrate reserve and supernatant containing the LMW fraction of carbohydrate reserve were separated and placed in an incubator at $50^{\circ} \mathrm{C}$ for drying. Dry samples of (1) structural carbohydrate, (2) LMW fraction and (3) HMW fraction of reserve carbohydrate were resuspended in $1 \mathrm{ml}$ of Milli-Q water. The different carbohydrate pools were quantified using the phenol/ $\mathrm{H}_{2} \mathrm{SO}_{4}$ assay described above (Dubois et al. 1956). Total cellular carbohydrate and all cellular carbohydrate pools were then normalized by cell abundance and expressed as fmol of carbon per cell (fmol C [glucose equivalent] cell ${ }^{-1}$ ). The present fluctuations in the cell carbohydrate contents (fmol C [glucose equivalent] cell $^{-1}$ ) will be discussed in regard to the total carbon and nitrogen cell content of Crocosphaera watsonii (fmol C cell-1 and fmol N cell $^{-1}$ ) described by Dron et al. (2012).

The soluble EPS fraction $(<0.2 \mu \mathrm{m})$ is an extracellular carbohydrate fraction released by cells, dissolved in water (Underwood et al. 1995, Klein et al. 2011); the fraction is obtained after filtration of the culture through a $0.2 \mu \mathrm{m}$ polycarbonate filter to discard the cells. Two distinct pools of soluble EPS that were present in the filtrate were identified according to their molecular weight: LMW and HMW (Underwood et al. 1995, 2004). In the present study, samples for determination of LMW and HMW fractions of soluble EPS were taken every $4 \mathrm{~h}$. LMW and HMW soluble EPS were obtained by the overnight cold-ethanol precipitation as described above (Underwood et al. 2004). The HMW fraction of soluble EPS is essentially found as polymeric and oligomeric molecules that precipitate in cold ethanol, whereas the LMW fraction of soluble EPS is mainly composed of monomeric molecules that do not precipitate (Underwood et al. 1995, Smith \& Underwood 2000). Because Crocosphaera watsonii cells are small, the centrifugation method previously used to separate cells (Underwood et al. 2004, Abdullahi et al. 2006) or wet sediments (Bellinger et al. 2005) from the supernatant containing the so-called 'colloidal carbohydrate fraction' was inefficient; the filtration method was therefore used instead. The colloidal fraction was further separated into colloidal-EPS and LMW EPS, referred to here as HMW and LMW soluble EPS, respectively. Carbohydrates of soluble EPS pools were then quantified using phenol/ $\mathrm{H}_{2} \mathrm{SO}_{4}$ (Dubois et al. 1956). Based on the soluble EPS concentrations ([EPS], fmol C [glucose equivalent] $\mathrm{l}^{-1}$ ) and knowing (1) the constant dilution rate of the culture $\left(D, \mathrm{~d}^{-1}\right.$, here $\left.0.2 \mathrm{~d}^{-1}\right)$, (2) the constant culture volume in the bioreactor $(V, 1$, here 51$)$, (3) the outflow debit $(Q, 1$ $\mathrm{d}^{-1}$, here $1 \mathrm{l} \mathrm{d}^{-1}$ ) and (4) the cellular abundance $\left(A b\right.$, cells $\left.\mathrm{l}^{-1}\right)$ the soluble EPS production rate (fmol $\mathrm{C}$ [glucose equivalent] cell ${ }^{-1} \mathrm{~d}^{-1}$ ) was calculated as follows:

$$
E_{\text {Flux }}=Q \times[\mathrm{EPS}] \times \Delta t
$$

where $E_{\text {Flux }}$ is the effluent (fmol C), and $\Delta t(\mathrm{~d})$ is the time interval between 2 samplings $\left(t_{2}-t_{1}\right)$.

$$
\begin{gathered}
\text { Soluble EPS production rate }= \\
{\left[V \times\left[\mathrm{EPS}_{t_{2}}\right]-V \times\left[\mathrm{EPS}_{t_{1}}\right]+E_{\mathrm{Flux}}\right] / \Delta t}
\end{gathered}
$$

expressed in fmol C (glucose equivalent) $\mathrm{d}^{-1}$.

Normalization by the cell abundance requires division of Eq. (2) by the following term:

$$
\left(A b_{t_{2}}+A b_{t_{1}}\right) /(2 \times V)
$$

The average EPS production rate in a specific period of time (i.e. average EPS production during the light or dark period) was calculated through linear regression of the corresponding EPS concentrations on the filters. Then, we averaged these rates 
over the 4 light or dark periods to get an average diel production rate in the light and in the dark.

\section{TEP analyses}

TEP are formed mainly by phytoplankton and from dissolved TEP-precursors and/or HMW soluble EPS released by organisms (Passow 2002). The acidic exo-polysaccharides that compose the TEP fraction can be stained with Alcian Blue, which specifically stains acidic mucopolysaccharides (Passow \& Alldredge 1995). The method of Claquin et al. (2008) was used to determine the concentration of TEP in xanthan equivalents per liter (Xequival $1^{-1}$ ) (Fig. 1); this method was adapted from Passow \& Alldredge (1995) (linear regression, $r^{2}=0.99$ ).

Samples for determination of TEP concentrations were taken every $4 \mathrm{~h}$. Aliquots of $5.8 \mathrm{ml}$ of culture were filtered through a $0.4 \mu \mathrm{m}$ polycarbonate filter at low vacuum pressure to preserve the cells, and the filters were stored at $-80^{\circ} \mathrm{C}$ until analysis. The filtrate was discarded. An aliquot of $2 \mathrm{ml}$ of $0.02 \%$ Alcian Blue (Sigma) in $0.06 \%$ acetic acid was added to the filter containing cells and TEP and centrifuged (3200 $\times g$, at $20^{\circ} \mathrm{C}$ for $30 \mathrm{~min}$ ) immediately to remove the excess dye. Pellets containing the filter with TEP were rinsed with $1 \mathrm{ml}$ of Milli-Q water and centrifuged 2 to 5 times $\left(3200 \times g\right.$, at $20^{\circ} \mathrm{C}$ for $\left.30 \mathrm{~min}\right)$; once uncolored, the supernatant was removed. A total of $4 \mathrm{ml}$ of $80 \%$ $\mathrm{H}_{2} \mathrm{SO}_{4}$ was added to the pellet. After a $2 \mathrm{~h}$ incubation, the absorption of the stained sample was measured at $787 \mathrm{~nm}$. TEP values were expressed as xanthan gum equivalent weight (mg Xequival $\mathrm{l}^{-1}$ ) calculated by the calibration standard preparation (Claquin et al. 2008). The carbon content of TEP (TEP-C) was estimated from colorimetric determinations:

$$
\text { TEP-C }=0.75 \times \mathrm{TEP}_{\text {color }}
$$

where TEP-C is given in $\mu \mathrm{g}$ and $\mathrm{TEP}_{\text {color }}$ in $\mu \mathrm{g}$ Xequival (Engel \& Passow 2001). Bearing in mind that the relationship between Alcian Blue adsorption and carbon content of TEP varies among phytoplankton species (Passow 2002), the possibility that the chosen mean conversion factor over- or underestimates TEP-C produced by Crocosphaera watsonii cannot be fully ruled out. It is noteworthy that diel changes, in terms of relative amplitude and pattern, are independent of the conversion factor.

Based on the TEP concentration and knowing the dilution rate $\left(\mathrm{d}^{-1}\right)$, it was possible to calculate the TEP production rate (fmol C cell ${ }^{-1} \mathrm{~h}^{-1}$ ) as described above.

\section{RESULTS}

The experiment showed strongly consistent results between the 2 replicate cultures (C1 and C2). Unless otherwise specified, results are provided as average values between the 2 cultures.

\section{Ultrastructure}

The ultrastructure of Crocosphaera watsonii showed a cell wall from 15 to $35 \mathrm{~nm}$ wide and remarkable, large inclusion granules mainly located at the cell periphery (Fig. 2). These granules were 115 to $320 \mathrm{~nm}$ in diameter (200 granules were observed) and appeared as regularly shaped spheres or oblate ellipsoids. Long, double invaginated membranes were observed around and between granule inclusions (Fig. 2b). Small (4 to $10 \mathrm{~nm}$ ) dark body inclusions and diffuse material were found in the cell. The cell division process appears initiated by symmetric invagination of both the cytoplasmic membrane and peptidoglycan layer (Fig. 2a).

\section{Total cellular carbohydrate and cellular carbohydrate pools}

The extreme values of total cellular carbohydrate observed during the $4 \mathrm{~d}$ experiment were 25 and 110 fmol C (glucose equivalent) cell ${ }^{-1}$ (Fig. 3a,b); the average values per culture, calculated over the $4 \mathrm{~d}$ period, were $55.5 \pm 9.4$ and $75.6 \pm 12.0 \mathrm{fmol} \mathrm{C}$ (glucose equivalent) cell $^{-1}$ (mean $\pm \mathrm{SD}, \mathrm{n}=19$ ) for $\mathrm{C} 1$ and $\mathrm{C} 2$, respectively. Diel fluctuations of the total cellular carbohydrate followed clear patterns over the light:dark cycle with a consistent trend repeated every day: on average over the $4 \mathrm{~d}$, total cellular carbohydrate increased during the light period (L1 to L12) from a minimum of $55.1 \pm$ 13.0 fmol $\mathrm{C}$ (glucose equivalent) cell $^{-1}$ to a maximum of $74.6 \pm 14.0$ fmol $\mathrm{C}$ (glucose equivalent) cell $^{-1}$ (mean $\pm \mathrm{SD}, \mathrm{n}=8$ ) and thereafter decreased during the dark period (D1 to D12) back to the minimum value, with a significant difference between the extrema ( $\mathrm{p}<0.05$, paired $t$-test; Fig. 3a). Thus, on a daily basis, an average of 19.5 fmol C (glucose equivalent) were accumulated per cell during the light (Fig. 4, Process d), and the same amount was thereafter degraded during the dark period (Fig. 4, Processes $\mathrm{g}, \mathrm{h}, \mathrm{k}, \mathrm{l}$ and respiratory).

Cellular carbohydrate pools also showed a daily pattern. The carbohydrate reserve of Crocosphaera 
watsonii varied from 24 to $47 \mathrm{fmol} \mathrm{C}$ (glucose equivalent) $\mathrm{cell}^{-1}$ (Fig. 3c), increasing during the light period, reaching a maximum at light to dark transition and subsequently decreasing in the dark, with a minimum at the dark to light transition. The daily, mean content of LMW fraction of carbohydrate reserve was $33.0 \pm 6.0 \mathrm{fmol} \mathrm{C}$ (glucose equivalent) cell $^{-1}$, and that of the HMW fraction of carbohydrate
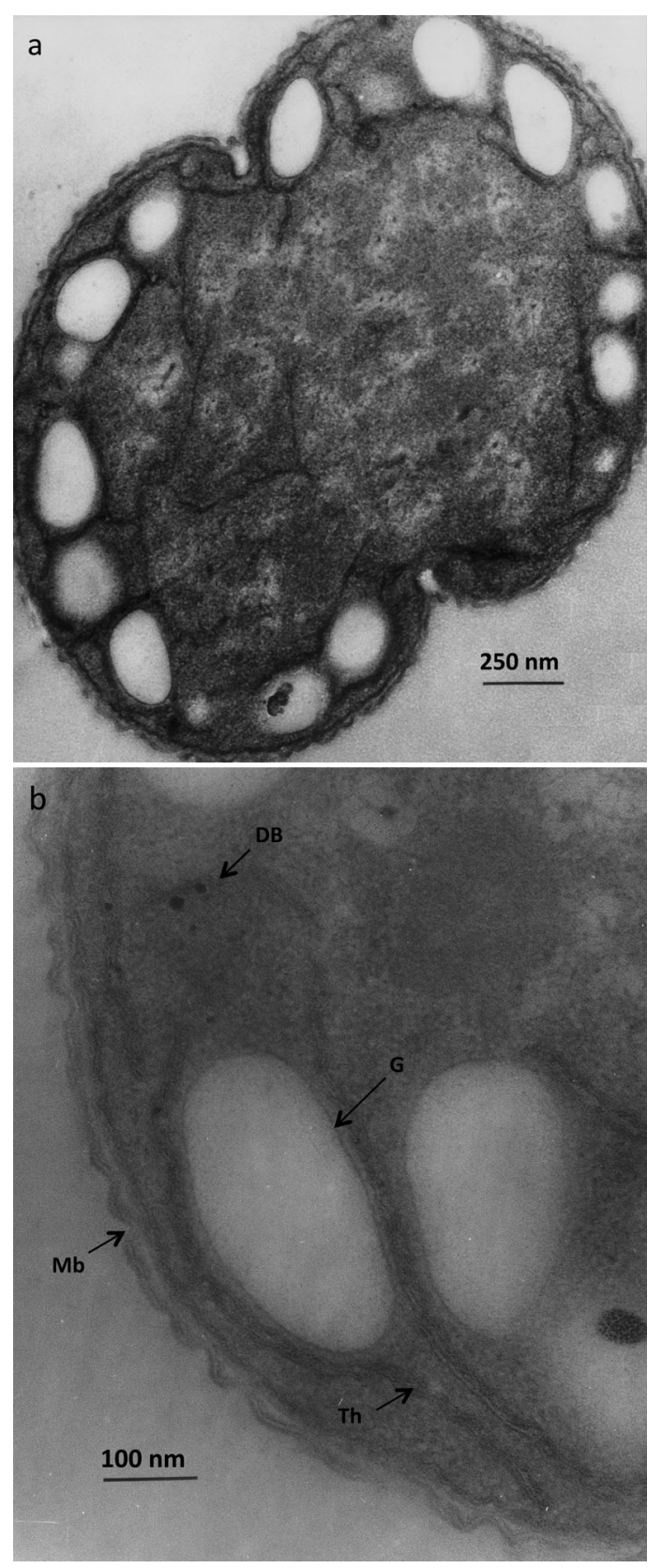

Fig. 2. Crocosphaera watsonii. Transmission electron microscopy of a C. watsonii cell during division. Th: thylacoid membrane; G: granule; DB: dark body; Mb: external membrane reserve was $5.7 \pm 2.1 \mathrm{fmol} \mathrm{C}$ (glucose equivalent) cell $^{-1}$ (mean $\pm \mathrm{SD}, \mathrm{n}=42$ ). The LMW carbohydrate reserve did not show any pattern of diel rhythmicity (Fig. 3d), contrary to the HMW carbohydrate reserve, which varied from 2 to 9 fmol C (glucose equivalent) cell $^{-1}$ (Fig. 3e). The average maximum contents of the HMW carbohydrate in the 2 cultures were observed at L9, reaching $7.9 \pm 0.9 \mathrm{fmol} \mathrm{C}$ (glucose equivalent) cell $^{-1}$, and decreased until D9, reaching a minimum of $3.4 \pm 0.8 \mathrm{fmol} \mathrm{C}$ (glucose equivalent) cell $^{-1}$ (mean $\pm \mathrm{SD}, \mathrm{n}=8$ ), with a significant difference between the extrema $(p<0.05$, paired $t$-test).

\section{Soluble EPS and TEP}

LMW soluble EPS production ranged from -1.5 to $2.2 \mathrm{fmol} C$ (glucose equivalent) cell ${ }^{-1} \mathrm{~h}^{-1}$. The LMW soluble EPS production rate was higher during the light period, even though the observed trends are not rigorously patterned on the light:dark cycle (Fig. 5a). On average, 7.4 and $4.6 \mathrm{fmol} \mathrm{C}$ (glucose equivalent) cell $^{-1}$ were produced in the light (Fig. 4, Process i) and in the dark period, respectively (i.e. $4 \mathrm{~d}$ average of LMW soluble EPS production during the light or dark period times the duration of the corresponding period; Fig. 4, Process k). HMW soluble EPS production was 5-fold lower on average than LMW soluble EPS production over the light:dark cycle, averaging 1.2 and $0.9 \mathrm{fmol} \mathrm{C}$ (glucose equivalent) cell ${ }^{-1}$ during the light (Fig. 4, Process j) and dark period (Fig. 4, Process 1), respectively.

TEP concentration, expressed in mg Xequival $\mathrm{l}^{-1}$ (non-normalized by the cell abundance) ranged between 1.0 and $2.4 \mathrm{mg}$ Xequival $\mathrm{l}^{-1}$, with an average of $1.64 \pm 0.44 \mathrm{mg}$ Xequival $\mathrm{l}^{-1}$ (mean $\pm \mathrm{SD}$, $\mathrm{n}=42$ ), and remained stable during the experiment (Fig. 6a). The TEP production showed a daily pattern, ranging from -2.3 to $2.8 \mathrm{fmol} \mathrm{C} \mathrm{cell}^{-1} \mathrm{~h}^{-1}$ (Fig. 6b), with a mean of $0.26 \mathrm{fmol} \mathrm{C}$ cell $^{-1} \mathrm{~h}^{-1}$ (mean $\pm \mathrm{SD}$, $\mathrm{n}=42$ ). TEP production appeared to increase and decrease during dark and light periods, when $5.33 \pm$ 1.09 (Fig. 4, Process h) and $1.41 \pm 2.19 \mathrm{fmol} \mathrm{C} \mathrm{cell}^{-1}$ were produced and lost, respectively.

\section{DISCUSSION}

The present study documents the diel patterns of accumulation and release of carbohydrate in the UCYN-B, Crocosphaera watsonii WH8501, growing exponentially under a light:dark regime. 


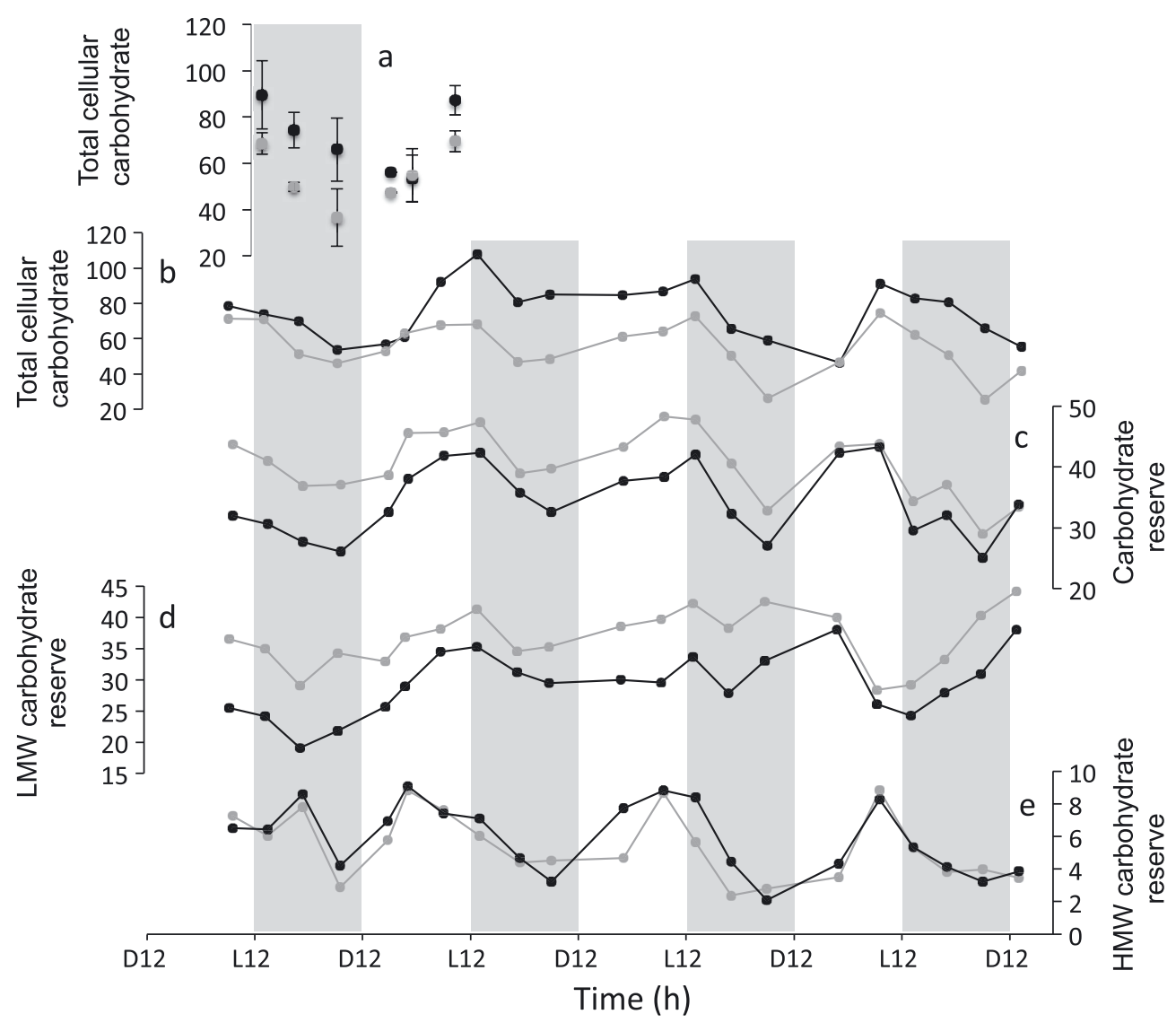

Fig. 3. Crocosphaera watsonii. (a) Four-day average of carbohydrate cell content at each time of sampling. Diel fluctuations in (b) total carbohydrate cell content and (c) reserve carbohydrate, including (d) low (LMW) and (e) high (HMW) molecular weight reserves in $C$. watsonii grown under a $12 \mathrm{~h}$ light:12 h dark (white and gray background, respectively) regime. Results for $\mathrm{C} 1$ and $\mathrm{C} 2$ cultures are represented by black and gray solid lines, respectively. D12: end of $12 \mathrm{~h}$ dark period; L12: end of $12 \mathrm{~h}$ light period; $y$-axes units: fmol C [glucose equivalent] cell $^{-1}$

\section{Crocosphaera watsonii accumulates carbohydrates}

The ultrastructural analysis of Crocosphaera watsonii revealed a consistent intracellular arrangement among the 200 cells observed from both the $\mathrm{C} 1$ and $\mathrm{C} 2$ cultures. The central, cytoplasmic region is known to contain chromatin, ribosomes and carboxysomes (not visible on the figures), while more conspicuous thylakoid membranes and large inter-thylacoidal inclusion bodies are found mainly at the cell periphery (Fig. 2). Aquatic cyanobacteria often include a large number of structures known as gas vacuoles, which confer vertical mobility in the water column in order to obtain light for photosynthesis (Graham et al. 2009). However, gas vacuoles are not delimited by membranes and are assemblies of vesicles, shaped as hollow, pointed cylinders (Graham et al. 2009), which were not observed here (Fig. 2). C. watsonii does not seem to possess such gas vesicles. The diameter of the inter-thylacoidal inclusion bodies measured in the present study (115 to $320 \mathrm{~nm}$ ) is comparable to the range of cellular carbohydrate granule diameter (150 to $250 \mathrm{~nm}$ ) of Cyanothece sp. (UCYN-C) (Reddy et al. 1993, Schneegurt et al. 1994).

In cyanobacteria, organic carbon produced by photosynthetic activity is predominantly stored as polymeric carbohydrates in granules (Shively 1988, Stanier 1988, Nakamura et al. 2005). The cyanophycean starch (polyglucan, also called glycogen) is the common carbohydrate storage found as $\alpha-1,4$ linked polyglucans (Graham et al. 2009). However, it has been shown that true starch is the form of carbohydrate storage in Crocosphaera watsonii (Deschamps et al. 2008). Considering that the LMW and/or HMW carbohydrate reserve is most probably contained in the carbohydrate granules (Fig. 3c), fluctuations of this reserve led us to postulate that the number and/or the size of carbohydrate granules rises and falls during the light and dark period, respectively, as previously observed in Cyanothece sp. 


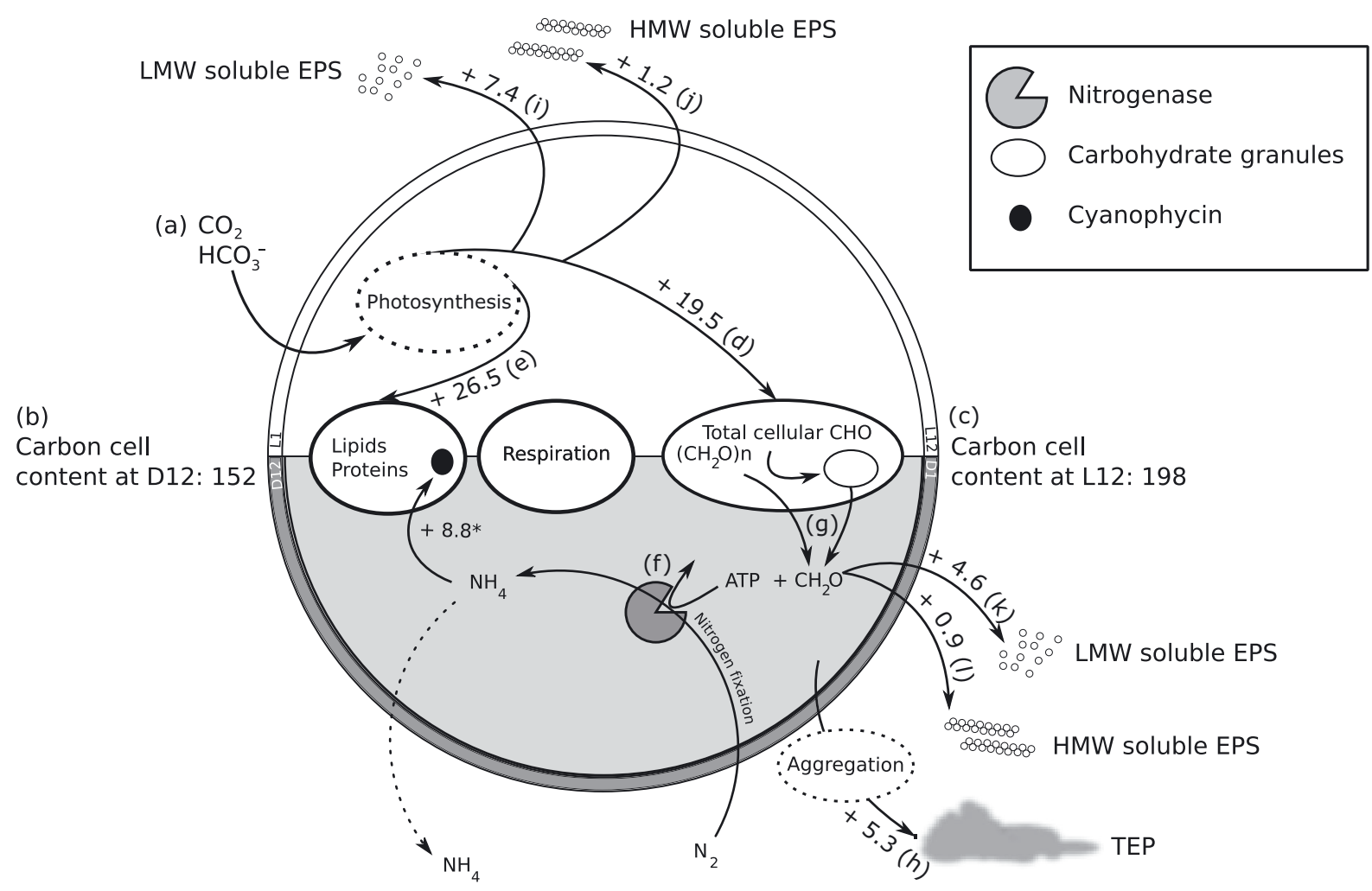

Fig. 4. Diel carbon and nitrogen metabolic pathways in Crocosphaera watsonii WH8501. TEP: transparent exopolymeric particles. All results are expressed in fmol C cell ${ }^{-1}$ except anabolism of nitrogen, expressed in fmol $\mathrm{N} \mathrm{cell}^{-1}$. The $4 \mathrm{~d}$ average of carbon cell content at (b) D12 and (c) L12 and (f) the net nitrogen accumulation during the dark period were taken from Dron et al. (2012), and that of (d) the net carbohydrate accumulation during the light period was taken from results presented in Fig. 3a. (e) Net protein/lipid (cellular material - carbohydrates) accumulation during the light period comes from the difference between the carbon and carbohydrate net accumulation during the light period $(=\mathrm{c}-\mathrm{b}-\mathrm{d})$. (h) The $4 \mathrm{~d}$ average of the dark TEP production was taken by averaging the TEP production during 4 night periods, presented in Fig. $\left.6 \mathrm{~b} \mathrm{(fmol} \mathrm{C} \mathrm{cell}{ }^{-1} \mathrm{~h}^{-1}\right)$, times the duration of the dark period (12 h). The (i) LMW and (j) HMW soluble EPS production, during the light or (k, l, respectively) dark periods were calculated similarly

(Reddy et al. 1993, Schneegurt et al. 1994, Liberton et al. 2011).

By comparing the total carbon cell content measured in the same cultures (Dron et al. 2012) (Fig. 4, Processes $\mathrm{b}$ and $\mathrm{c}$ ) to the present carbohydrate fractionations, it appears that total cellular carbohydrate, (1) synthesized during the light, accounts for nearly half $(45 \pm 3 \%)$ of the carbon cell content at L12 and (2) is catabolized during the dark, dropping to about a third $(32 \pm 4 \%)$ of the carbon cell content at D12 (Fig. 7). Quantification of the intracellular carbon fluxes was derived from the high frequency monitoring of the different pools. During the light period, the total carbon cell content increased by $46 \mathrm{fmol} \mathrm{C}$ (Dron et al. 2012) (Fig. 4, Processes b \& c), including a $19.5 \mathrm{fmol} \mathrm{C}$ increase of the total cellular carbohydrate (Figs. 3a \& 4, Process d). The remaining $26.5 \mathrm{fmol} \mathrm{C}$ were thus probably directed toward lipid, protein and nucleic acid syntheses (Fig. 4, Process e).
Our observations on the temporal segregation of carbohydrate anabolism and catabolism are in agreement with the light:dark cycle of total carbon cell content (Mohr et al. 2010, Dron et al. 2012). This suggests that variations in total carbon cell content are mainly due to carbohydrate cell fluxes. During the dark period, i.e. in the absence of photosynthesis, the energy and reducing power required for $\mathrm{N}_{2}$ fixation (Fig. 4, Process f) are supplied through catabolism of carbohydrate accumulated during the light period (Figs. 3a,b,e \& 4, Process g). The daily acquired carbon, in large excess compared to the cell requirements for biomass build-up, indicates that an important pool of small carbon molecules is potentially available to feed the respiration process, not only for the provision of ATP and reducing power (in particular for nitrogen fixation) but also to lower intracellular $\mathrm{O}_{2}$ concentration, which creates more favorable conditions for nitrogenase activity. 


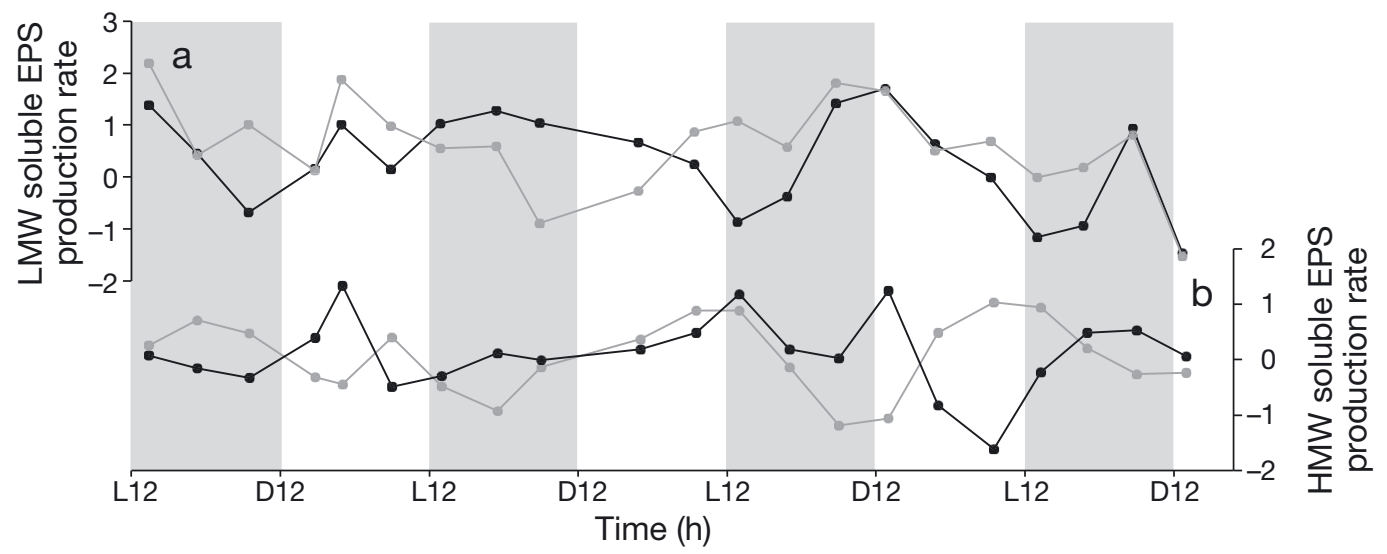

Fig. 5. Crocosphaera watsonii. Production (fmol C [glucose equivalent] cell ${ }^{-1} \mathrm{~h}^{-1}$ ) of soluble, extracellular polymeric substances (EPS): (a) low molecular weight (LMW soluble EPS) and (b) high molecular weight (HMW soluble EPS) in C. watsonii grown under a $12 \mathrm{~h}$ light:12 h dark (white and gray background, respectively) regime. Results for $\mathrm{C} 1$ and $\mathrm{C} 2 \mathrm{cultures}$ are rep resented by black and gray solid lines, respectively

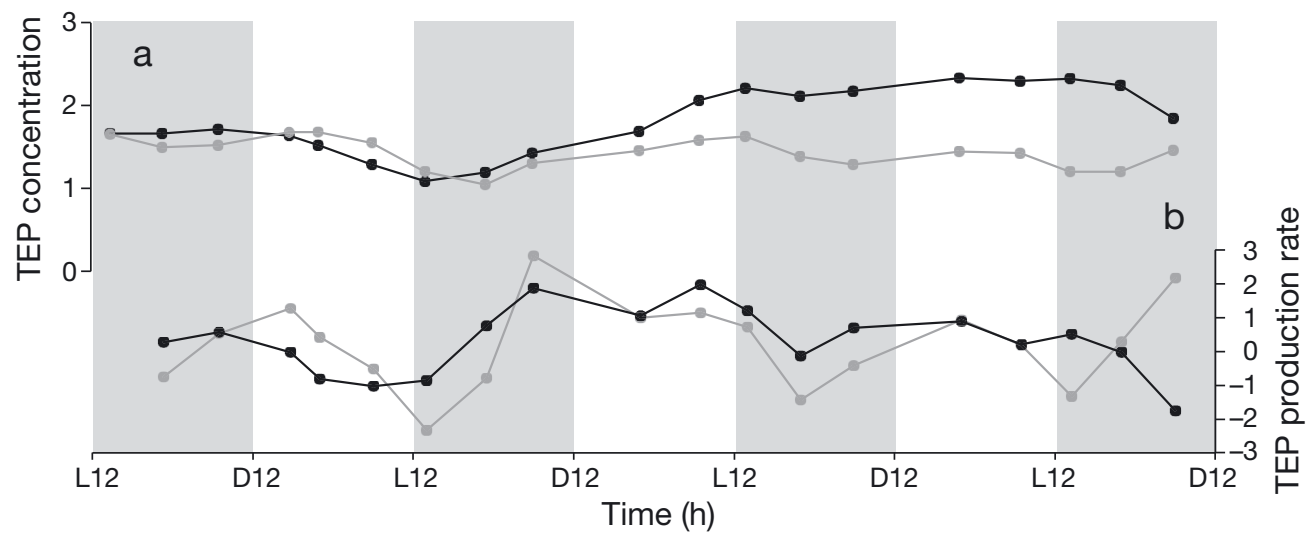

Fig. 6. Crocosphaera watsonii. (a) Transparent exopolymeric particle (TEP) concentration (mg Xequival $\mathrm{l}^{-1}$ ) and (b) TEP production (fmol C cell ${ }^{-1} \mathrm{~h}^{-1}$ ) of $C$. watsonii grown under a $12 \mathrm{~h}$ light:12 h dark (white and gray background, respectively) regime.

Results for $\mathrm{C} 1$ and $\mathrm{C} 2$ cultures are represented by black and gray solid lines, respectively

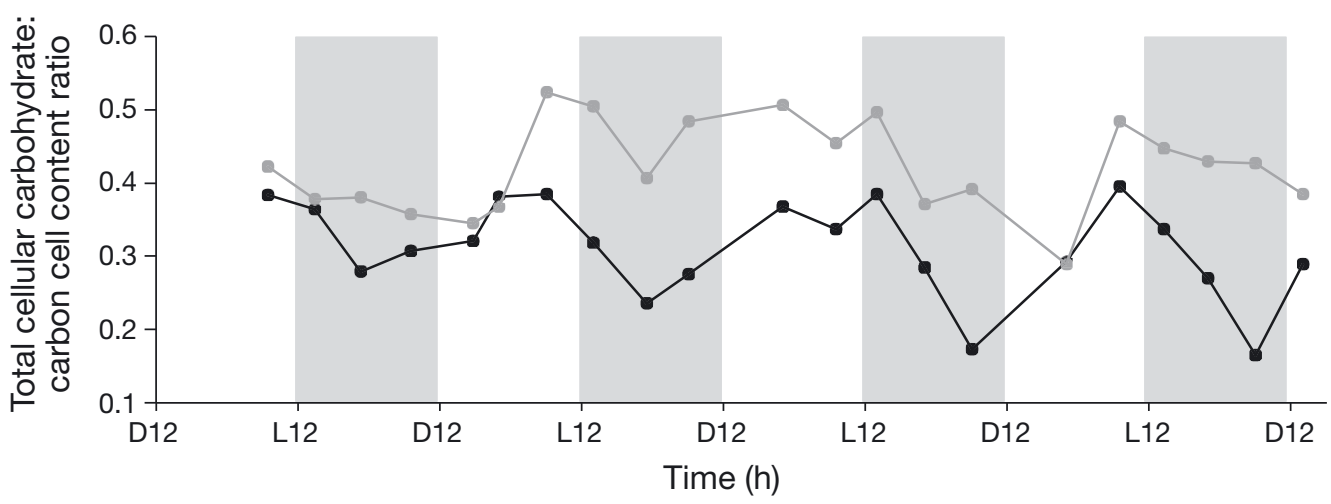

Fig. 7. Crocosphaera watsonii. Diel fluctuations in the total cellular carbohydrate:carbon cell content ratio of $C$. watsonii grown under a $12 \mathrm{~h}$ light:12 h dark (white and gray background, respectively) regime. Results for $\mathrm{C} 1$ and $\mathrm{C} 2$ cultures are represented by black and gray solid lines, respectively 


\section{Overproduction of organic carbon by Crocosphaera watsonii}

It has been suggested that some species, like freshwater diatoms and colonial cyanobacteria, might only form TEP during senescence (Passow 2002). In the present study, we demonstrated that Crocosphaera watsonii produces substantial amounts of TEP during the exponential growth phase in lightlimited cultures, under non-limiting nutrient conditions but diazotrophic growth. TEP are formed during the dark period, with an average production of $5.33 \pm 1.09 \mathrm{fmol} \mathrm{C}$ cell $^{-1} \mathrm{~d}^{-1}$ (Fig. 6b, mean $\pm \mathrm{SD}$, $\mathrm{n}=$ 8; summarized in Fig. 4, Process h), corresponding to $6.03 \pm 1.24 \mathrm{fg}$ Xequival $\mu \mathrm{m}^{-3} \mathrm{~d}^{-1}$; this is higher than rates reported for the diatoms Thalassiosira weissflogii, T. rotula and Melosira nummuloides and for the coccolithophorid Emiliana huxleyi, which produced 3, 3, 2 and $1 \mathrm{fg}$ Xequival $\mu \mathrm{m}^{-3} \mathrm{~d}^{-1}$, respectively (Passow 2002). Nevertheless, the TEP production rate of $C$. watsonii remains lower than that of most diatoms (e.g. $31 \mathrm{fg}$ Xequival $\mu \mathrm{m}^{-3} \mathrm{~d}^{-1}$ in Nitzschia sp., according to Passow 2002). Yet, the quantification of TEP produced by $C$. watsonii in the present study revealed that daily TEP production represented nearly $3.6 \%$ of the daily average total carbon content. C. watsonii thrives in the northwestern Atlantic and Pacific oceans, with abundances below $10^{3}$ cells $\mathrm{ml}^{-1}$ (Church et al. 2005, Zehr et al. 2007). The TEP cell production measured in our cultures suggests that natural populations of $C$. watsonii in the subtropical, oligotrophic areas could excrete daily a significant part of their organic carbon, up to $5.33 \mathrm{nmol} \mathrm{C}$ $\mathrm{ml}^{-1} \mathrm{~d}^{-1}$

At the daily scale, carbohydrates excreted as soluble EPS contain $\sim 85 \%$ of the labile LMW pool (Fig. 4, Processes i and k), which also includes monosaccharides and oligosaccharides. The LMW pool is more readily available for bacteria, and our present estimations indicate that soluble EPS excreted daily account for nearly $10 \%$ of the total carbon cell content. We therefore suspect that the growth of natural Crocosphaera watsonii populations is very likely to stimulate the microbial loop through the excretion of (1) carbon as a major part of LMW soluble EPS (the present study) and (2) nitrogen as ammonium or dissolved organic nitrogen (Dron et al. 2012).

During the exponential growth phase, there is apparently no down-regulation of carbohydrate excretion in Crocosphaera watsonii WH8501. In the light phase, when photosynthesis is active, the release of soluble EPS presumably results in one or both of the following: (1) an overflow of carbon within the cell during the photosynthetic light reactions, or (2) unbalanced nitrogen and carbon availability within the cell (Fig. 2 in Dron et al. 2012). The former suggests that the accumulation of carbon monomers, following $\mathrm{CO}_{2}$ reduction, would be too fast compared to the conversion process into glucan or to structural carbon. When these LMW sugars accumulate in the cytoplasm, osmotic and turgor pressure increase in the cell (Holland \& Walsby 2009), and a way to regulate these pressures would be to excrete LMW molecules as soluble EPS. The second hypothesis refers to the fact that carbon excretion promotes a rather constant ratio between sugar and protein contents (Orvain et al. 2003, Underwood et al. 2004), and such a balance has essentially been observed in non-diazotrophic species (Claquin et al. 2008). This second hypothesis may not hold for UCYN, which show timely decoupled dynamics of their carbon and nitrogen reserves and therefore a much more variable carbon:nitrogen ratio. Besides, soluble EPS production in C. watsonii is subject to diel cycles, and the results demonstrate that excretion occurs during both light and dark periods, and dark excretion can reach $40 \%$ of the daily soluble EPS excretion. Therefore, soluble EPS excretion cannot only be due to an overflow of photosynthesis. In the dark period, carbon consumption through respiration is enhanced to fuel metabolism and in particular the process of nitrogen fixation. This sugar catabolism generates small carbohydrate molecules, such as glucose-1-P, maltotetraose or maltopentose (Boos \& Shuman 1998). Even if most of them are reused in carbon metabolism (Ball \& Morell 2003), these molecules transiently increase cell turgor pressure, and we suspect that regulation of this pressure occurs through soluble EPS excretion. Hence, during the dark period, EPS excretion would be concomitant with $C$. watsonii carbon catabolism. We also wonder whether nocturnal excretion could provide an indirect ecological advantage to nitrogen fixation. We expect the activity of microbial flora surrounding or embedded in colonies to be stimulated by $C$. watsonii's excreted products, which might create hypoxic conditions during the $\mathrm{O}_{2}$-sensitive $\mathrm{N}_{2}$ fixation process. In addition, EPS excretion is also invoked as a possible chelator for micronutrients such as iron or calcium (De Philippis et al. 1991), which are both essential to diazotrophs for nitrogen fixation. Lastly, it has been hypothesized that EPS could also protect nitrogenase against harmful effects of oxygen in the cyanobacterium Nostoc cordubensis (Prosperi 1994). 
The observed circadian dynamics of carbon pools and the role of carbohydrate in total cell carbon raise the question of cell buoyancy as an ecological advantage. It is known that (1) carbohydrate variation over the light:dark cycle alters cell buoyancy, but (2) for migration to take place, colony formation is a prerequisite (Rabouille et al. 2005). EPS might favor aggregation, which then promotes vertical migration toward deeper layers. However, further experiments on aggregation are needed to validate this hypothesis because we never observed any clear aggregation of cells into spherically shaped colonies in our laboratory conditions.

When grown in batch conditions, i.e. without setting a given growth rate as imposed by the culture dilution rate, Crocosphaera watsonii can grow faster (0.3 to $0.5 \mathrm{~d}^{-1}$; Webb et al. 2009) than observed in the present study $\left(0.2 \mathrm{~d}^{-1}\right)$. Since the EPS production seems to be affected by the growth rate (Passow 2002), further studies will be necessary to determine whether C. watsonii is able to maintain such excretion under higher growth rates.

\section{CONCLUSION}

Our results emphasize that a significant proportion of total carbon in Crocosphaera watsonii WH8501 is composed of carbohydrates. Our transmission electron microscopy observations revealed large interthylacoidal granule inclusions distributed mostly at the cell periphery, which presumably contain these carbohydrate reserves. The results showed quantitative temporal changes in carbohydrate pools under exponential, diazotrophic growth and a $12 \mathrm{~h}$ light: 12 h dark cycle. C. watsonii also produces significant amounts of EPS (soluble EPS and TEP) in the light and in the dark, concomitantly to both processes of photosynthesis and $\mathrm{N}_{2}$ fixation (see dynamics presented by Dron et al. 2012). C. watsonii is depicted as an important provider of new nitrogen in the marine environment, and the present study suggests that natural populations of this species would also directly and significantly affect the biogeochemistry of the oceans by altering the dynamics of the microbial loop through the release of organic material.

Acknowledgements. The present study was supported by the LEFE-CYBER program CROCOCYCLE and the Conseil Général des Alpes Maritimes. We are grateful to B. Le Roy for technical assistance, M. L. Pedrotti for her constructive comments and J. Zehr for providing Crocosphaera watsonii WH8501.

\section{LITERATURE CITED}

Abdullahi AS, Underwood GJC, Gretz MR (2006) Extracellular matrix assembly in diatoms (Bacillariophyceae). V. Environmental effects on polysaccharide synthesis in the model diatom, Phaeodactylum tricornutum. J Phycol 42: 363-378

Alldredge AL, Passow U, Logan BE (1993) The abundance and significance of a class of large transparent organic particles in the ocean. Deep-Sea Res I 40:1131-1140

Ball SG, Morell MK (2003) From bacterial glycogen to starch: understanding the biogenesis of the plant starch granule. Annu Rev Plant Biol 54:207-233

Bellinger BJ, Abdullahi AS, Gretz MR, Underwood GJC (2005) Biofilm polymers: relationship between carbohydrate biopolymers from estuarine mudflats and unialgal cultures of benthic diatoms. Aquat Microb Ecol 38: 169-180

Bernard O, Malara G, Sciandra A (1996) The effects of a controlled fluctuating nutrient environment on continuous cultures of phytoplankton monitored by computers. J Exp Mar Biol Ecol 197:263-278

> Biegala IC, Raimbault P (2008) High abundance of diazotrophic picocyanobacteria $(<3 \mu \mathrm{m})$ in a Southwest Pacific coral lagoon. Aquat Microb Ecol 51:45-53

Boos W, Shuman H (1998) Maltose/maltodextrin system of Escherichia coli: transport, metabolism, and regulation. Microbiol Mol Biol Rev 62:204-229

> Chen YB, Zehr JP, Mellon MT (1996) Growth and nitrogen fixation of the diazotrophic filamentous nonheterocystous cyanobacterium Trichodesmium sp. IMS 101 in defined media: evidence for a circadian rhythm. J Phycol 32:916-923

Church MJ, Jenkins BD, Karl DM, Zehr JP (2005) Vertical distributions of nitrogen-fixing phylotypes at Stn ALOHA in the oligotrophic North Pacific Ocean. Aquat Microb Ecol 38:3-14

Claquin P, Probert I, Lefebvre S, Veron B (2008) Effects of temperature on photosynthetic parameters and TEP production in eight species of marine microalgae. Aquat Microb Ecol 51:1-11

> Colón-López MS, Sherman DM, Sherman LA (1997) Transcriptional and translational regulation of nitrogenase in light-dark- and continuous-light-grown cultures of the unicellular cyanobacterium Cyanothece sp. strain ATCC 51142. J Bacteriol 179:4319-4327

- Crowther RJ, Whittaker JR (1986) Differentiation without cleavage: multiple cytospecific ultrastructural expressions in individual one-celled ascidian embryos. Dev Biol 117:114-126

> de Brouwer JFC, Stal LJ (2001) Short-term dynamics in microphytobenthos distribution and associated extracellular carbohydrates in surface sediments of an intertidal mudflat. Mar Ecol Prog Ser 218:33-44

> De Philippis R, Sili C, Tassinato G, Vincenzini M, Materassi $R$ (1991) Effects of growth conditions on exopolysaccharide production by Cyanospira capsulata. Bioresour Technol 38:101-104

- Deschamps P, Colleoni C, Nakamura Y, Suzuki E and others (2008) Metabolic symbiosis and the birth of the plant kingdom. Mol Biol Evol 25:536-548

> Dron A, Rabouille S, Claquin P, Le Roy B, Talec A, Sciandra A (2012) Light-dark (12:12) cycle of carbon and nitrogen metabolism in Crocosphaera watsonii WH8501: relation to the cell cycle. Environ Microbiol 14:967-981 
Dubois M, Gilles KA, Hamilton JK, Rebers PA, Smith F (1956) Colorimetric method for determination of sugars and related substances. Anal Chem 28:350-356

Engel A (2000) The role of the transparent exopolymer particles (TEP) in the increase in apparent stickiness during the decline of a diatom bloom. J Plankton Res 22:485-497

Engel A, Passow U (2001) Carbon and nitrogen content of transparent exopolymer particles (TEP) in relation to their Alcian Blue adsorption. Mar Ecol Prog Ser 219:1-10

Gallon JR, Perry SM, Rajab TMA, Flayeh KAM, Yunes JS, Chaplin AE (1988) Metabolic changes associated with the diurnal pattern of $\mathrm{N}_{2}$ fixation in Gloeothece. J Gen Microbiol 134:3079-3087

Graham LE, Graham JM, Wilcox LW (2009) Algae, 2nd edn. Benjamin Cummings, San Francisco, CA

> Gundersen K, Heldal M, Norland S, Purdie DA (2002) Elemental $\mathrm{C}, \mathrm{N}$ and $\mathrm{P}$ content of individual bacteria collected at the Bermuda Atlantic Time-series Study (BATS) site. Limnol Oceanogr 47:1525-1530

> Hertkorn N, Benner R, Frommberger M, Schmitt-Kopplin P and others (2006) Characterization of a major refractory component of marine dissolved organic matter. Geochim Cosmochim Acta 70:2990-3010

Holland DP, Walsby AE (2009) Digital recordings of gasvesicle collapse used to measure turgor pressure and cell-water relations of cyanobacterial cells. J Microbiol Methods 77:214-224

Kepkay PE (2000) Colloids and the ocean carbon cycle. In: Wangersky PJ (ed) The handbook of environmental chemistry. Springer, Berlin, p 35-56

> Klein C, Claquin P, Pannard A, Napoléon C, Le Roy B, Véron B (2011) Dynamics of soluble extracellular polymeric substances and transparent exopolymer particle pools in coastal ecosystems. Mar Ecol Prog Ser 427:13-27

Liberton M, Austin II Jr, Howard Berg R, Pakrasi HB (2011) Unique thylakoid membrane architecture of a unicellular $\mathrm{N}_{2}$-fixing cyanobacterium revealed by electron tomography. Plant Physiol 155:1656-1666

Malara G, Sciandra A (1991) A multiparameter phytoplanktonic culture system driven by microcomputer. J Appl Phycol 3:235-241

Meedel TH, Chang P, Yasuo H (2007) Muscle development in Ciona intestinalis requires the b-HLH myogenic regulatory factor gene Ci-MRF. Dev Biol 302:333-344

Mohr W, Intermaggio MP, LaRoche J (2010) Diel rhythm of nitrogen and carbon metabolism in the unicellular, diazotrophic cyanobacterium Crocosphaera watsonii WH8501. Environ Microbiol 12:412-421

Myklestad SM (1995) Release of extracellular products by phytoplankton with special emphasis on polysaccharides. Sci Total Environ 165:155-164

Nakamura Y, Takahashi YI, Sakurai A, Inaba Y and others (2005) Some cyanobacteria synthesize semi-amylopectin Type a-polyglucans instead of glycogen. Plant Cell Physiol 46:539-545

> Orvain F, Galois R, Barnard C, Sylvestre A, Blanchard G, Sauriau PG (2003) Carbohydrate production in relation to microphytobenthic biofilm development: an integrated approach in a tidal mesocosm. Microb Ecol 45: $237-251$

Editorial responsibility: Douglas Capone,

Los Angeles, California, USA
Passow U (2002) Transparent exopolymer particles (TEP) in aquatic environments. Prog Oceanogr 55:287-333

Passow U, Alldredge AL (1995) A dye-binding assay for the spectrophotometric measurement of transparent exopolymer particles (TEP). Limnol Oceanogr 40:1326-1335

Prosperi CH (1994) A cyanophyte capable of fixing nitrogen under high levels of oxygen. J Phycol 30:222-224

Rabouille S, Salencon MJ, Thebault JM (2005) Functional analysis of Microcystis vertical migration: a dynamic model as a prospecting tool: I-Processes analysis. Ecol Model 188:386-403

> Reddy KJ, Haskell JB, Sherman DM, Sherman LA (1993) Unicellular, aerobic nitrogen-fixing cyanobacteria of the genus Cyanothece. J Bacteriol 175:1284-1292

Schneegurt MA, Sherman DM, Nayar S, Sherman LA (1994) Oscillating behavior of carbohydrate granule formation and dinitrogen fixation in the cyanobacterium Cyanothece sp. strain ATCC-51142. J Bacteriol 176:1586-1597

> Sciandra A, Ramani P (1994) The steady states of continuous cultures with low rates of medium renewal per cell. J Exp Mar Biol Ecol 178:1-15

Shively JM (1988) Inclusions: granules of polyglucose, polyphosphate, and poly- $\beta$-hydroxybutyrate. Methods Enzymol 167:195-203

Smith DJ, Underwood GJC (2000) The production of extracellular carbohydrates by estuarine benthic diatoms: the effects of growth phase and light and dark treatment. J Phycol 36:321-333

Sohm JA, Edwards BR, Wilson BG, Webb EA (2011) Constitutive extracellular polysaccharide (EPS) production by specific isolates of Crocosphaera watsonii. Front Microbiol 2:229

> Stanier (Cohen-Bazire) G (1988) Fine structure of cyanobacteria. Methods Enzymol 167:157-172

> Thornton DCO (2002) Diatom aggregation in the sea: mechanisms and ecological implications. Eur J Phycol 37 : 149-161

> Underwood GJC, Paterson DM, Parkes RJ (1995) The measurement of microbial carbohydrate exopolymers from intertidal sediments. Limnol Oceanogr 40:1243-1253

> Underwood GJC, Boulcott M, Raines CA, Waldron K (2004) Environmental effects on exopolymer production by marine benthic diatoms: dynamics, changes in composition, and pathway of production. J Phycol 40:293-304

Waterbury JB, Rippka R (1989) Cyanobacteria. Subsection I. Order Chroococcales. In: Krieg NR, Holt JB (eds) Bergey's manual of systematic bacteriology, Vol 3. Williams \& Wilkins, Baltimore, MD, p 1728-1746

Webb EA, Ehrenreich IM, Brown SL, Valois FW, Waterbury JB (2009) Phenotypic and genotypic characterization of multiple strains of the diazotrophic cyanobacterium, Crocosphaera watsonii, isolated from the open ocean. Environ Microbiol 11:338-348

Zehr JP, Waterbury JB, Turner PJ, Montoya JP and others (2001) Unicellular cyanobacteria fix $\mathrm{N}_{2}$ in the subtropical North Pacific Ocean. Nature 412:635-638

Zehr JP, Montoya JP, Jenkins BDJ, Hewson I and others (2007) Experiments linking nitrogenase gene expression to nitrogen fixation in the North Pacific subtropical gyre. Limnol Oceanogr 52:169-183

Submitted: May 3, 2012; Accepted: September 17, 2012 Proofs received from author(s): November 12, 2012 